Журнал «Герспективитаінноваціїнауки»

(Серія «Гедагогіка», Серія «Гиихологія»), Серія«Медицина»

№5(5) 2021

УДК: $796.08+159.9$

https://doi.org/10.52058/2786-4952 -2021-5(5)-542-553

Подгорна Вікторія Віталіївна кандидат наук з корекційної педагогіки, доцент кафедри фізичного виховання та спорту, Національний університет «Одеська політехніка», пр. Шевченка 1, м. Одеса, 65044, тел.: (063) 079-79-63, e-mail: podgorna.v.v@op.edu.ua, https://orcid.org/0000-0003-3395-8314

Смолякова Ірина Дмитрівна кандидат наук 3 теорії та методики навчання (фізична культура, основи здоров'я), доцент, завідувач кафедри фізичного виховання та спорту, Національний університет «Одеська політехніка», пр. Шевченка 1, м. Одеса, 65044, тел.: (096) 441-82-73, e-mail: i.d.smolyakova@opu.ua, https://orcid.org/0000-0002-8500-5817

Апенько Дарина Василівна студентка 3 курсу, Національний університет «Одеська політехніка», пр. Шевченка 1, м. Одеса, 65044, тел.: (050) 224-48-95, e-mail: apenko.808947@ stud.op.edu.ua, https://orcid.org/0000-0002-3845-6981

\title{
ВПЛИВ СИЛОВИХ ТРЕНУВАНЬ НА ПСИХОЕМОЦІЙНИЙ СТАН СТУДЕНТІВ
}

Анотація. Актуальність дослідження обумовлена наявністю безлічі об'єктивних і суб'єктивних факторів, які призводять до стану депресії на етапі студентства. Особливо це стосується здобувачів вищої освіти, які брали участь у бойових діях в окупованих територіях України. Вибір теми дослідження обумовлений припущенням, що заняття атлетизмом рекреаційної спрямованості підвищить рівень самопочуття та позитивно позначиться на стані здоров'я студентської молоді. Метою дослідження стало вивчення змін суб'єктивних показників психоемоційного стану студентів 18-20 років в процесі силових тренувань. В результаті проведеного дослідження був підтверджений антидепресійний вплив силових навантажень за результатами самооцінки студентів. Дослідження особистої тривожності показало, що іiі значення мають тенденцію до зниження в наслідок регулярних силових тренувань. Встановлено, що після навантажень, спрямованих на розвиток абсолютної сили, спостерігається збільшення показників самопочуття, активності і настрою. Це свідчить про те, що дозовані силові навантаження 3 максимальною або близько-максимальною вагою є тонізуючим фактором, що проявляється при суб'єктивних відчуттях. За результатами аналізу суб'єктивних показників встановлено, що при використанні навантажень, спрямованих на розвиток абсолютної сили показники самопочуття, активності, настрою поліпшуються; застосування навантажень, пов'язаних 3 проявом силової витривалості, негативно впливають на показники самопочуття і активності, але 
підвищують рівень настрою; найбільш бажаними для поліпшення суб'єктивних показників виявилися вправи з використанням тренажерів, які спрямовані на розвиток власне силових якостей. Позитивний вплив силових тренувань на ставлення до свого здоров'я у студентів був підтверджений більш високими показниками в порівнянні з вихідним і проміжним тестуванням. У контрольній групі було зафіксовано зниження показників підсумкового тестування в порівнянні з вихідним рівнем, що відображає загальну негативну тенденцію, яка виражається в погіршенні здоров'я студентської молоді.

Ключові слова: фізичне виховання, фізична рекреація, силові вправи, спортивне тренування, депресивні стани, студенти.

Podhorna Viktoriia Vitaliivna Candidate of Sciences in Correctional Pedagogy, Associate Professor of Physical Education and Sports, National University "Odessa Polytechnic", 1 Shevchenko Ave., Odessa, 65044, tel .: (063) 079-79-63, e-mail: podgorna.vv @ op.edu.ua, https://orcid.org/00000003-3395-8314

Smoliakova Iryna Dmytrivna Candidate of Sciences in Theory and Methods of Teaching (Physical Education, Fundamentals of Health), Associate Professor, Head of the Department of Physical Education and Sports, National University "Odessa Polytechnic", 1 Shevchenko Ave., Odessa, 65044, tel .: (096) 441-82-73, e-mail: idsmolyakova@opu.ua, https://orcid.org/0000-0002-8500-5817

Apenko Daryna Vasylivna 3rd year student, National University "Odessa Polytechnic", 1 Shevchenko Ave., Odessa, 65044, tel .: (050) 224-48-95, e-mail: apenko.808947@stud.op.edu.ua, https://orcid.org/0000-0002-3845-6981

\section{THE INFLUENCE OF STRENGTH TRAINING ON THE PSYCHO- EMOTIONAL STATE OF STUDENTS}

Abstract. The relevance of the study is due to the presence of many objective and subjective factors that lead to depression in the student stage. This is especially true of applicants for higher education who took part in hostilities in the occupied territories of Ukraine. The choice of the research topic is conditioned by the assumption that recreational athletics will increase the level of well-being and have a positive effect on the health of student youth. The aim of the study was to study the changes in the subjective indicators of the psycho-emotional state of students aged 18-20 in the process of strength training. As a result of the study, the antidepressant effect of force loads was confirmed based on the results of students' self-assessment. A study of personal anxiety has shown that its value tends to decrease as a result of regular strength training. It is established that after the loadings directed on development of absolute force, increase in indicators of state of health, activity and mood is observed. This indicates that dosed power loads with maximum or near- 
maximum weight is a tonic factor that manifests itself in subjective sensations. According to the results of the analysis of subjective indicators it is established that at use of the loadings directed on development of absolute force indicators of state of health, activity, mood improve; the use of loads associated with the manifestation of strength endurance, negatively affect the indicators of well-being and activity, but increase the level of mood; the most desirable for the improvement of subjective indicators were exercises with the use of simulators, which are aimed at the development of self-strength qualities. The positive effect of strength training on the attitude to their health in students was confirmed by higher rates compared to the initial and intermediate testing. In the control group, there was a decrease in the indicators of final testing compared to baseline, which reflects the general negative trend, which is expressed in the deterioration of the health of student youth.

Keywords: physical education, physical recreation, strength exercises, sports training, depressive states, students.

Постановка проблеми. У студентському віці загострені так звані кризові моменти в соціальному розвитку молодих людей. Можна, принаймні, виділити три таких вузлові моменти: перший - перехід від статусу школяра до статусу здобувача вищої освіти; другий - адаптація до нових форм навчання, до нового соціального середовища; третій - перехід до «дорослості».

Основна проблема, з якою стикаються викладачі фізичного виховання в 3ВО, полягає в протиріччі між необхідністю зміцнення і збереження психофізичного здоров'я студентів і відсутністю 3 їх боку реальних кроків у цьому напрямі. Найбільш типовими проблемами $є$ високий рівень депресивних станів, зниження мотивації, низький рівень фізичної підготовленості, недостатнє забезпечення з боку ЗВО потреб молоді в різноманітних формах фізичного виховання.

Корекція параметрів процесу відновлення та збереження психофізичного здоров'я обумовлена змінами фізичного та психоемоційного станів студентів. Одним 3 напрямів сучасних технологій є комплексне використання різних засобів і їхніх поєднань. Рішення задачі виховання ціннісного ставлення до фізичної культури і власного здоров'я нами уявляється в використанні рекреаційного напряму і досягається, коли особистісні цінності фізичної культури відчуті студентами, усвідомлені як життєво необхідні, ціннісні орієнтації підкріплені активною фізкультурно-спортивною діяльністю.

Аналіз останніх досліджень і публікацій. Здобуття освіти в ЗВО автори відносять до специфічного виду діяльності, пов'язаного 3 підвищеними вимогами до розв'язання проблемних ситуацій, твердим контролем i регламентацією навчального режиму, 3 високим рівнем психічних навантажень, які загострюються в сесійні періоди у зв'язку з дефіцитом часу, необхідністю засвоювати великий обсяг інформації в стислі терміни $[1,7,10]$.

Депресивні та стресові стани у студентів - це сфера дослідження педагогів [ 5, 6, 8], психологів [1, 7] та медиків [2, 3, 4]. Загальновідомо, що заняття різними видами фізичної активності позитивно впливають на 
психофункціональні здатності людини $[3,5,8,9]$.

На жаль, на етапі студентства існує безліч об'єктивних і суб'єктивних факторів, які призводять до стану депресії. В спеціальній літературі розрізняють патологічну депресію, яка $\epsilon$ одним 3 основних психіатричних відхилень, та функціональні стани депресії, які можуть виявлятися у здорових людей в межах нормального психічного функціонування [4].

Під депресією ми розуміємо стан, який характеризується пригніченим настроєм, загальмованістю мислення, зниженням активності, уповільненням рухів і мовлення, порушенням сну. У стані депресії людина відчуває негативні емоції i хвилювання. Загальний психологічний стан забарвлюється заперечливим емоційним фоном, зниженням рівня мотивації, загальною пасивністю поведінки. Відзначено, що в цей час різко знижується рівень мотивації та вольової активності. 3'являються настирливі подумки про відповідальність за різноманітні власні неприємності, а також неприємності, які трапились 3 друзями і близькими. Результатом є знижена самооцінка [7, 10].

Силові тренування як вид діяльності є одним 3 точних і якісних інструментів самооцінки людини, ऑї фізичного i психічного «Я» $[5,9]$. Це поширений тип тренінгудля розвитку сили i розміру скелетних м'язів за якого використовується сила тяжіння через зважені бари, гантелі або ваги стеків, і в якості потужного антистресового засобу в роботах науковців він не розглядався.

Мета дослідження: встановити зміни суб'єктивних показників психоемоційного стану студентів 18-20 років в процесі силових тренувань.

Виклад основного матеріалу. Для досягнення мети роботи були використані такі методи дослідження: теоретичний аналіз i узагальнення літературних даних, педагогічні спостереження, методи реєстрації суб'єктивних показників (дослідження депресії, самооцінка адекватності, самооцінка компонентів здорового способу життя), тестування здорового способу життя, педагогічний експеримент, методи математичної статистики.

Для реєстрації суб'єктивних показників ефекту занять 3 обтяженнями різного спрямування був використаний тест «САН»: самопочуття, активність, настрій (за А.Б. Леоновою, 1984). Студентам було запропоновано оцінити свій стан за 30 критеріями. Перша третина критеріїв характеризує стан самопочуття, друга активності, третя - настрою. Нульове значення шкали відповідає нейтральному значенню («ні хороше, ні погане»). Порівняння стану проводилося за всіма показниками на початку та наприкінці річного циклу силових тренувань.

Дослідження самооцінки особистої тривожності проводилось за допомогою опитувальника за методикою Ч.Спілбергера, в якому наведені чотири ступеня тривожності з присвоєнням балів від 1 до 4. Критерії особистої тривожності розташовані в зонах:

до 30 балів - низький рівень тривожності,

30-45 балів - середній рівень тривожності,

вище 45 балів - високий рівень тривожності.

Дослідження депресії проводилося за допомогою опитувальника, 
Журнал«Герспективитаінновації наукиљ

(Серія«Гедагогіка»), Серія«ГТихологія», Серія «Медицина»

№5(5) 2021

розробленого для диференціальної діагностики депресивних станів і станів, близьких до депресії (Т.І.Балашова, 1996). Рівень депресії (РД) розраховується за формулою 1:

$$
\text { Рд }=\sum п р+\sum \text { звор. }
$$

де $\sum$ пр. - сума закреслених цифр до «прямих» висловлювань номера 1, 3, $4,7,8,9,10,13,15,19$;

$\sum$ звор. - сума цифр «зворотних», закреслених до висловлювань під номерами $2,5,6,11,12,14,16,17,18,20$. Наприклад: у висловлювання номер 2 закреслена цифра 1 , ми ставимо в суму 4 бали; у висловлювання номер 5 закреслено відповідь 2, ми ставимо в суму 3 бали; у висловлювання номер 6 закреслено відповідь 3 - ставимо в суму 2 бали; у висловлювання номер 11 закреслено відповідь 4 - ставимо в суму один бал і т.д.

Шкала оцінки депресії:

20 - 30 балів - повна відсутність депресії, низька тривожність;

$31-45$ балів - середня тривожність;

46 - 60 балів - елементи депресії, висока тривожність;

61 - 70 балів - підвищена депресивна акцентуація характеру;

71 - 80 балів - власне депресія.

Подолання депресивних переживань вимагає мобілізації функцій самооцінки.

Самооцінка адекватності. Розмах варіювання оцінок від 0 до 60 балів. Критерії самооцінки: менше 10 балів - завищена самооцінка; від 10 до 30 адекватна самооцінка, більше 30 балів - недоцінка себе.

Самооцінка компонентів здорового способу життя була проведена за допомогою анонімного опитування 3 градацією відповідей за принципом «від шкідливого до корисного». Розшифровка: відповідь «а» оцінюється в 4 очки, «б»2, «в» - 0. Шкала оцінки рівня компонентів здорового способу життя: від 38 до 56 балів високий; від 19 до 37 балів - середній; від 0 до 18 балів - низький рівень.

Дослідження проводились в 2020-2021 навчальному році. В ньому взяли участь 50 студентів Національного університету «Одеська політехніка», віком 18-20 років, з них 28 юнаків і 22 дівчини.

Одним 3 компонентів самопізнання в процесі занять руховою активністю $€$ самооцінка. Самооцінку ми розглядаємо як елемент самосвідомості, що характеризується емоційно-насиченими оцінками самого себе як особистості, своїх можливостей, моральних якостей і вчинків. Адекватна самооцінка $\epsilon$ важливим регулятором поведінки.

Нами було проведено опитування 3 метою дослідження впливу занять силовими вправами на самооцінку студентів за фактором «депресія». Цей критерій був обраний не випадково. За офіційними даними в сучасній Україні фіксується тенденція збільшення числа суїцидів.

Було встановлено, що на запитання про режим харчування 29,8\% юнаків і $43,2 \%$ дівчини відповіли, що харчуються, як доведеться. Нерегулярне харчування, недосипання, стресові стани під час модульних контрольних робіт, 
заліків та іспитів призводить до того, що 36,1\% юнаків і 25,3\% дівчат не задоволені своїм станом здоров'я. Тому не випадково, що 59,4\% юнаків і $65,2 \%$ дівчат зверталися протягом навчального року за медичною допомогою до лікаря $(10,3 \%$ юнаків і 14,8\% дівчат зверталися за допомогою більше трьох разів).

Обробка результатів опитування по самооцінці депресії дозволила отримати дані про розподіл стану тривожності по відповідних зонах. У зоні низької тривожності знаходяться 27,4\% відповідей юнаків і 13,2\% дівчат; в зоні середньої тривожності - 23,2\% юнаків і 25,5\% дівчат; в зоні високої тривожності 3 елементами депресії - 34,1\% юнаків і 35,9\% дівчат; в зоні підвищеної депресивної акцентуації характеру - 12,8\% юнаків і 20,1\% дівчат; безпосередньо в діапазоні депресії - 1,8\% відповідей юнаків і 4,3\% відповідей дівчат.

Основними причинами переважання відповідей у зоні високої тривожності для юнаків був ризик незадовільних оцінок в сесійний період, $\mathrm{i}$ тим самим позбавлення відстрочки від служби в армії. Для дівчат - основним мотивом було розставання з близькими і друзями.

Порівнюючи загальні дані про ризик виникнення депресії з результатами опитувань групи з 18 студентів, які почали займатися силовими вправами 3 обтяженнями, можна констатувати, що для них характерні нижчі результати рівня тривожності. Більшість показників депресії в цій групі студентів знаходиться в другій зоні - 9 осіб (середня тривожність), у 7 студентів відзначена низька тривожність або повна відсутність депресії, а показники високої тривожності були зафіксовані у двох студентів. Отже, протягом року показники в категорії високої тривожності у юнаків знизилися до рівня 30,4\%, відповідно покращилися показники в зонах середньої і низької тривожності. Цей факт обумовлюється комплексним впливом занять з обтяженнями на стан фізичного i психічного здоров'я, поліпшенням позитивної самооцінки, підвищенням статусу студентів, які займаються силовими вправами, в соціальній групі, підвищенням впевненості в своїх силах, адекватною самооцінкою своїх можливостей. В подальшому ці 18 студентів будуть складати експериментальну групу (ЕГ) нашого дослідження. Для зіставлення результатів дослідження методом випадкової вибірки було сформовано контрольну групу (КГ) з юнаків, які не займалися фізичними вправами. Дані наведені в таблиці1.

Таблиия 1

Динаміка рівня самооцінки студентів 18-20 років у КГ $(\mathbf{n}=18)$ та $\mathrm{E} \Gamma(\mathbf{n}=18)$

\begin{tabular}{|c|c|c|c|}
\hline \multirow{2}{*}{ Групи } & \multicolumn{3}{|c|}{ Етапи вимірювання } \\
\cline { 2 - 4 } & $\begin{array}{c}\text { на початку } \\
\text { експерименту }\end{array}$ & $\begin{array}{c}\text { проміжний } \\
\text { контроль }\end{array}$ & $\begin{array}{c}\text { наприкінці } \\
\text { експерименту }\end{array}$ \\
\hline КГ & $40 \pm 3,1$ & $43 \pm 2,4$ & $41 \pm 2,7$ \\
\hline ЕГ & $38 \pm 3,3$ & $39 \pm 3,5$ & $31 \pm 2,01$ \\
\hline
\end{tabular}


Журнал «Герспективитаінноваціїнауки»

(Серія«Гедагогіка», Серія«ГЕихологія», Серія «Медицин»

№5(5) 2021

Встановлено, що показники первинного вимірювання рівня самооцінки в КГ та ЕГ знаходилися в зоні заниженої самооцінки (середні показники для КГ становили 40 балів; для ЕГ - 38 балів). Відмінності в групах були статистично достовірними $(\mathrm{p}>0,5)$.

Процентне співвідношення розподілу самооцінок у КГ було розподілене таким чином: завищена самооцінка $-11 \%$; адекватна - $11 \%$; занижена $-78 \%$. В ЕГ $17 \%$ відповідей доводилося на зону завищеної самооцінки і $83 \%$ на зону заниженої самооцінки. Ці дані, на наш погляд, відображають характерні зміни, які відбуваються у юнаків, а саме: адаптація до нових соціальних умов, напруженого навчального процесу, який відрізняється від школи величезною кількістю інформації, методів іiї передачі тощо. До речі, кількість заниженої самооцінки в ЕГ можна пояснити тим, що юнаки, які почали займатись атлетизмом, більше, ніж інші не задоволені зовнішнім виглядом, станом розвитку мускулатури тощо.

Друге тестування проводилося в період зимової сесії. Наявність стресової ситуації вплинула на показники вимірювання рівня самооцінки, загальний рівень якої був вище як в КГ, так і в ЕГ, у порівнянні з початковим тестуванням. У КГ не було відзначено показників у зоні завищеної самооцінки. Більшість відповідей (84\%) припало на зону недооцінки своїх можливостей. В ЕГ у цій зоні перебувало $80,2 \%$ всіх відповідей. У зоні завищеної оцінки було $6 \%$ і в зоні адекватної самооцінки - $12 \%$ відповідей.

Підсумкове тестування наприкінці експерименту показало деяке зниження середнього значення самооцінки в порівнянні з попереднім тестуванням в КГ (41 бал проти 43 балів). В ЕГ значно підвищився процентний рівень адекватної самооцінки, який склав 53\% при середньому значенні 31 бал. Цей показник знаходиться поруч 3 межею адекватної самооцінки групи в цілому. Отже, можна стверджувати про позитивний вплив занять 3 обтяженнями в корекції самооцінки студентів.

Ця тенденція підтверджується дослідженням особистої тривожності за методикою Ч. Спілбергера (табл.2). При першому тестуванні (початок навчального року, вересень) показники в ЕГ знаходилися на рівні 43 балів, показники в КГ - 44 балів.

Таблиия 2

Динаміка показників особистої тривожності студентів 18-20 років впродовж навчального року

\begin{tabular}{|c|c|c|c|}
\hline \multirow{2}{*}{$\begin{array}{c}\text { Етапи } \\
\text { тестування }\end{array}$} & \multirow{2}{*}{ Групи } & \multicolumn{2}{|c|}{ Рівень тривожності у балах } \\
\hline & & $X \pm S x$ & Рівень достовірності \\
\hline \multirow{2}{*}{ Вересень 2020} & $\overline{\mathrm{K} \Gamma}$ & $44,5 \pm 1,4$ & \multirow{2}{*}{$\mathrm{p}<0,5$} \\
\hline & $\mathrm{E} \Gamma$ & $43,7 \pm 1,4$ & \\
\hline \multirow{2}{*}{ Грудень 2020} & KГ & $46,1 \pm 1,4$ & \multirow{2}{*}{$\mathrm{p}<0,5$} \\
\hline & $\mathrm{E} \Gamma$ & $44,1 \pm 1,2$ & \\
\hline \multirow{2}{*}{ Травень 2021} & КГ & $45,6 \pm 0,9$ & \multirow{2}{*}{$\mathrm{p}<0,05$} \\
\hline & $\mathrm{E} \Gamma$ & $42,2 \pm 1$ & \\
\hline
\end{tabular}


Отримані показники були неоднорідними. Встановлено, що в період сесії в грудні показники особистої тривожності зростають в обох групах. Причому в КГ зміна показників знаходились в зоні достовірних відмінностей $(p<0,5)$. Після підсумкового тестування в травні встановлено достовірна відмінність між показниками в КГ та ЕГ $(\mathrm{p}<0,05)$.

Показники особистої тривожності в КГ та ЕГ мають різну динаміку. У КГ спостерігається достовірне збільшення особистої тривожності. Отже, дані підсумкового тестування в травні мають більш високі значення в порівнянні 3 початковим виміром у вересні. Значення особистої тривожності в ЕГ мають тенденцію до зниження наприкінці навчального року. Це є підтвердженням позитивного впливу силового тренування на психоемоційний стан студентів ЕГ.

Для визначення впливу силових навантажень на різні стани суб'єктивного відчуття студентів використовувався опитувальник САН (самопочуття, активність, настрій). Тестування проводилося до і після тренувальних занять 3 різними силовими навантаженнями (на розвиток абсолютної сили, силової витривалості і власне-силових якостей).

Встановлено, що після навантажень, спрямованих на розвиток абсолютної сили (вправи зі штангою, змагальні та спеціально-підготовчі вправи з арсеналу пауерліфтингу) спостерігалось збільшення показників самопочуття, активності і настрою. Наприклад, показники самопочуття змінилися в бік поліпшення 3 $0,02 \pm 0,1$ бала, до $1,1 \pm 0,1$ бала. Така ж позитивна динаміка була відзначена за розділами активності (від - 0,1 $\pm 0,1$ до 0,9 \pm 0,1 бала) і настрою (від $0 \pm 0,1$ до $1 \pm 0,1$ бала). Це свідчить про те, що дозовані силові навантаження 3 максимальним або близько-максимальним обтяженням $\epsilon$ тонізуючим фактором, що проявляється при суб'єктивних відчуттях (табл. 3).

Таблицяя 3

Показники суб'сктивних станів студентів 18-20 років при різних напрямах силового тренування на початку та наприкінці заняття

\begin{tabular}{|l|c|c|c|c|c|c|}
\hline \multirow{2}{*}{$\begin{array}{l}\text { Показники } \\
\text { Напрям }\end{array}$} & \multicolumn{2}{|c|}{ Самопочуття } & \multicolumn{2}{c|}{ Активність } & \multicolumn{2}{c|}{ Настрій } \\
\cline { 2 - 7 } & $-0,02 \pm 0,1$ & $1,1 \pm 0,1$ & $-0,1 \pm 0,1$ & $0,9 \pm 0,1$ & $0,01 \pm 0,1$ & $1 \pm 0,1$ \\
\hline $\begin{array}{l}\text { розвиток абсолютної } \\
\text { сили }\end{array}$ & $0,5 \pm 0,1$ & $-0,1 \pm 0,1$ & $0,1 \pm 0,2$ & $\begin{array}{l}-0,2 \\
0,2\end{array}$ & $-0,1 \pm 0,2$ & $0,9 \pm 0,1$ \\
\hline $\begin{array}{l}\text { розвиток силової } \\
\text { витривалості }\end{array}$ & $-0,01 \pm 0,1$ & $1,4 \pm 0,1$ & $-0,2 \pm 0,1$ & $1,7 \pm 0,1$ & $-0,3 \pm 0,2$ & $1,2 \pm 0,1$ \\
\hline $\begin{array}{l}\text { розвиток власне- } \\
\text { силових якостей }\end{array}$ & & & & & & \\
\hline
\end{tabular}

При використанні навантажень, пов'язаних 3 розвитком силової витривалості (змагальні та спеціально-підготувальні вправи з гирями), було зафіксовано як позитивний, так і негативний вплив цього виду навантаження. Так зокрема, було відмічено зниження показників самопочуття (початкове 
значення $0,5 \pm 0,1$ бала; кінцеве $-0,1 \pm 0,1$ бала) і активності (початкове значення $0,1 \pm 0,1$ бала; кінцеве $-0,2 \pm 0,2$ бала).

Одночасно в позитивному напрямі змінилися показники настрою: 3

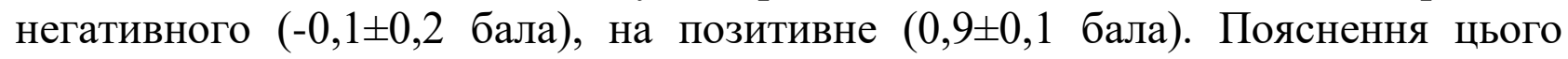
факту пов'язане 3 тим, що при навантаженнях, спрямованих на розвиток силової витривалості, використовувався інтервальний метод тренування. Проміжки часу для відпочинку між підходами були обмежені. За цей час студенти не встигали відновитися, і подальша робота тривала на тлі наростаючого стомлення, що водночас позначилося на таких суб'єктивних показниках, як самопочуття i активність. Однак безпосередньо силове тренування справило позитивний вплив на настрій у цілому, чому, на наш погляд, сприяв емоційний фон, що супроводжує заняття. Це і спілкування в групі, і вплив на слухові (музика в залі) і зорові (яскраве світло в залі) аналізатори, і елементи самоствердження, при підніманні гир і подоланні наступаючого стомлення.

Найбільші значення при поліпшенні суб'єктивного стану були зафіксовані при тренуванні на тренажерних пристроях (навантаження, яке спрямоване на розвиток власне-силових якостей). Так, показники самопочуття покращилися на 1,39 бала ( $3-0,01 \pm 0,1$ до $1,4 \pm 0,1$ бала), активності на 1,5 бала ( $3-0,2 \pm 0,1$ до $1,7 \pm 0,1$ бала) і настрою на 0,9 бала ( 3

$-0,3 \pm 0,2$ до $1,2 \pm 0,1$ бала). Ми схильні інтерпретувати позитивні зміни тим, що при роботі на тренажерних пристроях створюються найкомфортніші умови при виконанні силових вправ, ніж при тренуваннях 3 вільними обтяженнями (зі штангою або гирями). Задається певна траєкторія рухів, вправи виконуються з різних вихідних положень (в основному це сидячи або лежачи), вага обтяжень невелика (6-10 кг). Сам пристрій тренажерів зводить до мінімуму зусилля поступального характеру, які створюються при опусканні в початкове положення вільних обтяжень.

Наступним кроком дослідження було вивчення зміни показників здорового способу життя (ЗСЖ) у різні періоди навчання в ЗВО: вересень (вихідні дані, початок навчання), грудень (сесійний період), травень (сесійний період). Опитування, яке було проведене серед студентів, виявило статистично достовірні відмінності в показниках ЗСЖ (табл. 4).

Таблиия 4

Динаміка рівня здорового способу життя в КГ та ЕГ на різних етапах дослідження

\begin{tabular}{|c|c|c|c|}
\hline \multirow{2}{*}{ Групи } & \multicolumn{3}{|c|}{ Показник ЗСЖ по етапах тестування } \\
\cline { 2 - 4 } & вересень & грудень & Травень \\
\hline КГ & $19,7 \pm 3,4$ & $16,9 \pm 3,3$ & $18,3 \pm 3,1$ \\
\hline $\mathrm{E} \Gamma$ & $21,2 \pm 3,9$ & $20,1 \pm 3,6$ & $24,7 \pm 3,4$ \\
\hline
\end{tabular}

Вихідні показники рівня ЗСЖ у ЕГ були вище в порівнянні з КГ (21,2 23,9 балів проти 19,7 3,4 балів). Відмінності між показниками були статистично 
достовірними $(\mathrm{p}<0,5)$. Це пояснюється тією обставиною, що студенти, які хотіли займатися силовими вправами, схильні вести здоровий спосіб життя.

Проміжне тестування проводилося в грудні в сесійний період. В цей час було встановлено зниження показників ЗСЖ, як в КГ, так i в ЕГ. Так, показники в КГ знизилися з рівня 19,7 $\pm 3,4$ балів до 16,9 $\pm 3,3$ балів (p>0,5). В ЕГ зниження склало від 21,2 $\pm 3,9$ балів до 20,1 $\pm 3,6$ балів (p>0,5). Зниження показників, на наш погляд, було пов'язане зі стресовим чинником контрольного періоду, хронічною нестачею часу для спокійної підготовки до заліків та екзаменів. Слід зазначити, що хоча в ЕГ також відбулося зниження показників рівня ЗСЖ, але величина зниження була значно менше, ніж у КГ.

Результати підсумкового тестування свідчать про те, що в ЕГ значно підвищилися показники ставлення до ЗСЖ. Так, збільшення змін, у порівнянні 3 початковими показниками, склала рівень $321,2 \pm 3,9$ балів до $24,7 \pm 3,4$ балів ( $<<0,5)$. Зміни насамперед торкнулися таких компонентів ЗСЖ: зниження показників куріння і вживання спиртних напоїв; зниження рівня роздратування та стресу; поліпшення режиму харчування; задоволення навчальним процесом; встановлення хороших відносин з близькими та друзями.

У КГ відбулося погіршення показників ЗСЖ у порівнянні з вихідними показниками. Середні показники вихідного рівня дорівнювали 19,7 3,4 балів, кінцеві $-18,3 \pm 3,1$ балів (p>0,5). Погіршення торкнулося таких компонентів ЗСЖ: вживання спиртних напоїв і куріння; погіршення стану здоров'я; погіршення відносин з батьками; підвищення дратівливості та стресу.

Висновки. За результатами аналізу проведеного дослідження можна укласти основні аспекти впливу силових тренувань на психоемоційний стан студентів:

1. Силові навантаження можуть здійснювати як позитивний, так i негативний вплив на суб'єктивні показники.

2. При використанні навантажень, спрямованих на розвиток абсолютної сили (вправи зі штангою) показники самопочуття, активності і настрою змінилися в бік поліпшення.

3. Застосування навантажень, пов'язаних з проявом силової витривалості негативно вплинули на показники самопочуття i активності, але підвищили рівень настрою в порівнянні з показниками, зафіксованими до тренування.

4. Найбільш бажаними 3 погляду поліпшення суб'єктивних показників самопочуття, активності i настрою виявилися вправи 3 використанням тренажерів, які спрямовані на розвиток власне силових якостей.

Отримані показники підтверджують дані літературних джерел про тенденції погіршення фізичного і психічного здоров'я студентської молоді. При підсумковому тестуванні були відзначені більш високі показники в ЕГ у порівнянні 3 вихідним i проміжним тестуванням. Це доводить факт позитивного впливу занять з обтяженнями на ставлення до свого здоров'я у студентів. У КГ було зафіксовано зниження показників підсумкового тестування в порівнянні з вихідним рівнем, що відображає загальну негативну тенденцію, яка виражається в погіршенні здоров'я майбутніх фахівців. 


\section{Jimepamypa:}

1. Агаркова А. I. Схильність до депресії як чинник суїцидальної поведінки серед студентської молоді. Вісник Харківського національного педагогічного університету імені Г. С. Сковороди. Психологія, 2017. № 56. С. 19-29

2. Бобро О. В. До проблеми виникнення стресових розладів. Менеджмент підприємницької діяльності: навч. посіб. для проф. підготовки військовослужбовців ЗС України звільнених у запас. Проект «УкраїнаНорвегія». Одеса: Видавничий дім «Гельветика», 2020. № 8. С. 267-272

3. Гутарєва Н. В., Мусхаріна Ю. Ю., Гутарєв В. В., Яблочанська Е. Є. Вплив фізичної реабілітації на відновлення фізичного і психічного стану студентів вищих навчальних закладів. Український журнал медицини, біології та спорту, 2018. № 7. С. 278-282

4. Психотерапия детей и подростков / под ред. Ф. Кендалла. - 2-е изд. - СПб.: Питер, 2002. $-432 \mathrm{c}$

5. Подгорна В., Смолякова I, Дроздова К. Вплив специфіки спортивної діяльності на виховання міжособистісного спілкування та колективної взаємодії студентів. Modern management: theories, concepts, implementation. Monograph. Editors: Marian Duczmal, Tetyana Nestorenko. Opole: The Academy of Management and Administration in Opole, 2021, c. 286-293.

6. Слухенська Р. В., Пасько Т. В., Пашкова О. С. Роль керованих фізичних навантажень у профілактиці виникнення хронічного стресу. Педагогіка формування творчої особистості у вищій і загальноосвітній школах, 2018. № 58-59. С. 198-206.

7. Стоян Н. В. Психогігієнічна оцінка ступеня вираження астенічного і депресивного станів студентів у динаміці навчання в медичному вищому навчальному закладі. Гігієна населених місць, 2015. № 3. С. 244-249.

8. Тимошенко В. В., Булига В. С. Вплив фізичних навантажень на психоемоційний та фізичний стан студентів вищих навчальних закладів. Педагогіка і сучасні аспекти фізичного виховання, 2017. № 7. С. 92-95.

9. Тукаєв С., Вашека Т., Долгова О., Погорільська Н., Иваскевич Д., Федорчук С. Аматорський спорт як засіб запобігання емоційному вигоранню. Спортивна медицина, фізична терапія та ерготерапія, 2020. № 2. С. 18-25

10. Футорний С., Рудницький О. Характеристика стану здоров'я студентів вищих навчальних закладів. Теорія і методика фізичного виховання і спорту, 2013. №. 2. С. 99-105

\section{References:}

1. Aharkova, A.I. (2017). Skhyl'nist' do depresiyi yak chynnyk suyitsydal'noyi povedinky sered student's'koyi molodi [Predisposition to depression as a factor of suicidal behavior among student youth] Visnyk Kharkivs'koho natsional'noho pedahohichnoho universytetu imeni H. S. Skovorody. Psykholohiya - Bulletin of Kharkiv National Pedagogical University named after GS Skovoroda. Psychology, 56, 19-29 [in Ukrainian].

2. Bobro, O.V. (2020). Do problemy vynyknennya stresovykh rozladiv [On the problem of stress disorders]. Menedzhment pidpryyemnyts'koyi diyal'nosti - Entrepreneurship Management (pp. 267-272). Odesa: VD «Hel'vetyka» [in Ukrainian].

3. Hutaryeva N.V., Muskharina YU. YU., Hutaryev V.V., \& Yablochans'ka E.YE. (2018). Vplyv fizychnoyi reabilitatsiyi na vidnovlennya fizychnoho i psykhichnoho stanu studentiv vyshchykh navchal'nykh zakladiv [The impact of physical rehabilitation on the restoration of physical and mental condition of students of higher educational institutions.]. Ukrayins'kyy zhurnal medytsyny, biolohiyi ta sportu - Ukrainian Journal of Medicine, Biology and Sports, 7. 278-282 [in Ukrainian].

4. Kendall F. (Eds.). (2002). Psikhoterapiya detey i podrostkov [Psychotherapy of children and adolescents]. Saint Petersburg: VTD Piter [in Russian].

5. Podhorna, V., Smolyakova, I., \& Drozdova, K. (2021). Vplyv spetsyfiky sportyvnoyi diyal'nosti na vykhovannya mizhosobystisnoho spilkuvannya ta kolektyvnoyi vzayemodiyi 
studentiv [The influence of the specifics of sports activities on the education of interpersonal communication and collective interaction of students]. Modern management: theories, concepts, implementation. Monograph. (pp. 286-293). Opole: The Academy of Management and Administration in Opole [in Ukrainian].

6. Slukhens'ka, R.V., Pas'ko, T.V. \& Pashkova, O.S. (2018) Rol' kerovanykh fizychnykh navantazhen' u profilaktytsi vynyknennya khronichnoho stresu [The role of controlled physical activity in the prevention of chronic stress]. Pedahohika formuvannya tvorchoyi osobystosti $u$ vyshchiy $i$ zahal'noosvitniy shkolakh - Pedagogy of creative personality formation in higher and secondary schools. 58-59. 198-206. [in Ukrainian].

7. Stoyan, N.V. (2015). Psykhohihiyenichna otsinka stupenya vyrazhennya astenichnoho i depresyvnoho staniv studentiv u dynamitsi navchannya $\mathrm{v}$ medychnomu vyshchomu navchal'nomu zakladi [Psychohygienic assessment of the degree of expression of asthenic and depressive states of students in the dynamics of education in medical higher education]. Hihiyena naselenykh mists Hygiene of populated areas. 3. 244-249 [in Ukrainian].

8. Tymoshenko, V.V., Bulyha, V.S. (2017). Vplyv fizychnykh navantazhen' na psykhoemotsiynyy ta fizychnyy stan studentiv vyshchykh navchal'nykh zakladiv [The influence of physical activity on the psycho-emotional and physical condition of students of higher educational institutions]. Pedahohika $i$ suchasni aspekty fizychnoho vykhovannya - Pedagogy and modern aspects of physical education. 7. 92- 95 [in Ukrainian].

9. Tukayev, S., Vasheka, T., Dolhova, O., Pohoril's'ka, N., Yvaskevych, D., Fedorchuk, C. (2020). Amators'kyy sport yak zasib zapobihannya emotsiynomu vyhorannyu [Amateur sports as a means of preventing emotional burnout]. Sportyvna medytsyna, fizychna terapiya ta erhoterapiya Sports medicine, physical therapy and occupational therapy. 2. 18-25 [in Ukrainian].

10. Futornyy, S., Rudnyts'kyy, O. (2013). Kharakterystyka stanu zdorov"ya studentiv vyshchykh navchal'nykh zakladiv [Characteristics of the state of health of students of higher educational institutions]. Teoriya $i$ metodyka fizychnoho vykhovannya $i$ sportu - Theory and methods of physical education and sports. 2.99-105 [in Ukrainian]. 